\title{
Morphology, Pathogenicity and Molecular Identification of Fusarium spp. Associated with Anise Seeds in Serbia
}

\author{
Snežana PAVLOVIĆ ${ }^{1 *}$, Danijela RISTIĆ ${ }^{2}$, Ivan VUČUROVIĆ ${ }^{2}$, \\ Miloš STEVANOVIĆ ${ }^{2}$, Saša STOJANOVIĆ ${ }^{2}$, Slobodan KUZMANOVIĆ \\ Mira STAROVIĆ ${ }^{2}$
}

\author{
${ }^{1}$ Institute for Medicinal Plant Research "Dr. J. Pančic', T. Košćuška 1, Belgrade, \\ Serbia; snezanapavlovic47@gmail.com ( ${ }^{*}$ corresponding author); \\ ${ }^{2}$ Institute for Plant Protection and Environment, Teodora Drajzera 9, Belgrade, Serbia; risticdaca@yahoo.com; vucurovic.ivan@gmail.com; \\ stevanovicmilos14@yahoo.com; sale.stoj@gmail.com; kuzmanovic@beotel.net; miragavranstarovic@gmail.com
}

\begin{abstract}
Anise (Pimpinella anisum L.) is an important medicinal spice plant that belongs to the family Apiaceae. Anise seeds are rich in essential oils and this is a reason why anise production in Serbia has increased over the last decade. During a routine health inspection on anise seeds collected from three localities in the province of Vojvodina (Mošorin, Veliki Radinci and Ostojićevo) during 2012 and 2013, it was found out that Fusarium spp. were a commonly observed fungi. The presence of Fusarium fungi on the seed samples ranged from $3.75-13.75 \%$. The aim of this study was to isolate and identify the strains of Fusarium species present on anise seed samples as it is necessary that commercially used anise seeds are completely free of Fusarium. Based on morphological, microscopic characteristics and a molecular identification by sequencing of TEF gene, the presence of the following species was confirmed on the anise seeds: F. tricinctum, F. proliferatum, F. equiseti, F. oxysporum, F. sporotrichoides, F. incarnatum and $F$. verticillioides. According to our knowledge and research, this is the first report of $F$. tricinctum and $F$. sporotrichoides as pathogens on anise seeds in the world. All seven isolates of Fusarium species are pathogenic to the anise seedlings, while the most virulent species were F. oxysporum, F. tricinctum and F. incarnatum.
\end{abstract}

Keywords: morphological characteristics, Pimpinella anisum, PCR detection, seed infection

\section{Introduction}

Anise (Pimpinella anisum L.) is an annual medicinal plant that belongs to the family Apiaceae, widely cultivated for its fruit and essential oils. Anise is an important raw natural material mostly used in medicine, perfumery and cosmetic industries (Simon et al., 1984). Due to increasing demand, anise production has increased in Serbia during the last decade (Dražić et al., 2007).

The mycoflora of anise seeds has not been studied sufficiently. Bokhari (2007) found out that the dominant species on the anise seeds in Saudi Arabia were from the genus Aspergillus. The same results were obtained by Saleem et al. (2013), while Saber et al. (2009) found Puccinia pimpinellae on anise seeds in Egypt. Several fungal species of the 21 genera, have been reported to be associated with anise seeds in Egypt (Ghoneem et al., 2012), the predominant species being Alternaria alternata, Drechslera tetramera, Cladosporium sp. and Stemphiulium sp., while the species from genus Fusarium were present in a low percentage. Bulajić et al. (2009) identified Alternaria alternation on anise seeds in Serbia. Knowing which seed-borne pathogens are present in or on anise seeds, is of practical importance as this affects the transmission mode of the pathogens. One of the important means of the disease transmission is through seeds. Planting infected seeds may result in a widespread distribution of disease within the crop, and an increased number of initial infection sites from which the disease can spread (Desjardins, 2006). As the fungi are the largest group of pathogens, it is almost impossible to keep the seeds completely pathogen free. In addition, the presence of the fungi in medicinal plants reduces their quality and usefulness (Essono et al., 2007). The use of chemical fungicides for plant disease control can be problematic as currently, some may have carcinogenic and teratogenic 
412

characteristics as well as residual toxicity (Skandamis et al., 2001).

Numerous fungi produce mycotoxins. The fungi from genus Fusarium contain zearalenone, fumonisin, moniliformin, fusarin and other toxins (Desjardins, 2006; Frisvad et al., 2006). The quality of anise is determined mainly on the basis of the essential oil content and its composition (Orav et al., 2008). If anise seeds contain mycotoxins, this will be toxic to humans and represents a threat to public health (Jackson and Jablonski, 2004). Fungi of the genus Fusarium are already reported to cause seed "rot" disease that affects different stages of the host, seeds, seedlings and the crowns of developing plants (MoyaElizando, 2013). When seed rot and seedling blight are caused by the same organism, seedlings fail to emerge due to a pathogen attack either before or after germination. There are a number studies on the mode of attack by Fusarium on ungerminated seeds. Numerous investigations have been conducted with Fusarium species that infect maize seed (Fandohan et al., 2003; Duncan et al., 2010; Madania et al., 2013). In a more specialized study regarding the mode of seed infection by Fusarium species, Sauerborn et al. (1996) showed the manner of pathogen penetration in the seed.

Fusarium spp. is widespread fungi, which can cause diseases on host plants with a serious economic impact (Wang et al., 2011). The morphological characteristics such as: the colony colour, growth rate, size and shape of macroand microconidia, formation of chlamydospores and conidiogenous cells, have been used as preferred methods for identification of Fusarium species (Summerell et al., 2003). However, the genus Fusarium is complex and morphological differences may be difficult to observe. Therefore, the DNA analysis is needed for accurate identification and characterization of the species. Molecular data in addition to the distinctive morphological characteristics have been used to identify Fusarium species by many authors (Geiser et al., 2004; Wang et al., 2011; Zhu et al., 2014).

The presence of Fusarium subglutinans has already been detected in anise seed during 2011 in Serbia (Ristić et al., 2015). Based on all these studies, the aim of this investigation was to (i) identify other Fusarium species on anise seeds, (ii) check incidence of seed infection and (iii) observe pathological effects of the Fusarium species in vivo.

\section{Materials and Methods}

\section{Samples}

The samples were collected during 2012 and 2013 from each of the three localities in the Vojvodina Province, Republic of Serbia: Mošorin ( $45^{\circ} 18^{\prime} \mathrm{N}, 20^{\circ} 09^{\prime} \mathrm{E}, 111 \mathrm{~m}$ above sea level), Veliki Radinci ( $45^{\circ} 02^{\circ} \mathrm{N}, 19^{\circ} 40^{\circ} \mathrm{E}, 110 \mathrm{~m}$ above sea level) and Ostojićevo ( $45^{\circ} 54^{\prime} \mathrm{N}, 20^{\circ} 09^{\prime} \mathrm{E}, 88 \mathrm{~m}$ above sea level). Sampling was conducted on the commercially available, organically produced anise seed $\mathrm{N}-210 \mathrm{cv}$. three months after harvesting.

An analysis of the health status was performed by the incubation of anise seeds on the filter paper and on the potato dextrose agar (PDA). Four hundred seeds ( 4 trials, each with 100 seeds) from each locality were sterilized with $\mathrm{NaOCl}$ for 3 minutes and then rinsed with sterile water and transferred to the filter paper on Petri dishes, $15 \mathrm{~cm}$ in diameter. Ten seeds from each locality in four repetitions were transferred to the PDA medium following the seed surface sterilization. After the eight-day incubation at $25^{\circ} \mathrm{C}$, parts of the mycelia taken from well-developed colonies were transferred to the PDA in order to be further examined (Mathur and Kongsdal, 2003). According to the appearance of mycelia, seven isolates were selected (A6, A7, A8, A9, A10, A11 and A12) for further investigations. The Fusarium spp. present on each seed was recorded as percentage of infected seeds in two investigated years.

\section{Morphologicalcharacterization}

Pure cultures obtained from a single spore of each isolate were grown on PDA incubated at $25^{\circ} \mathrm{C}$, with a 12 -h photoperiod and examined macroscopically (colony morphology and pigmentation) and microscopically (the shape, size and type and manner of conidia formation, production of microconidia, macroconidia, conidiogenous cells, chlamydospores, sclerotia) after 14 days. A hundred micro- and macroconidia were measured in every isolate. The isolates were identified according to the morphological characteristic described by Leslie and Summerell, (2006).

\section{The pathogenicity test}

Fifty 30 days-old anise seedlings grown under controlled condition on the filter paper were selected for their healthy and uniform appearance for the pathogenicity test. The roots of the healthy seedlings were injured using scissors and then soaked for $30 \mathrm{~min}$ in the spore suspension of the Fusarium sp. isolates in order to infect the root cells. Fusarium spore concentration of $5 \times 10^{6}$ conidia $\mathrm{ml}^{-1}$ was measured by a haemacytometer. The control plants were planted in the sterile soil without any spore suspensions. After inoculation, the plants were potted in the sterilized soil and grown in the glasshouse with day and night temperatures of $27-30{ }^{\circ} \mathrm{C}$ and $23-25^{\circ} \mathrm{C}$ respectively. Four replications were performed for each isolate. A development of symptoms of root necrosis on the inoculated and control plants was observed after 30 days. The level of root necrosis was calculated according to the scale 0-3 (0 - a healthy seedling, 1 root tip necrosis, 2 - root and lower part of the stem necrosis, 3 completely rotted). The intensity of infection (II) was calculated according to the modified Mc-Kinney's formula by Filion et al. (2003):

$$
\begin{aligned}
& \mathrm{II}=\sum(\mathrm{nv}) / 4 \mathrm{~N}^{*} 100, \\
& \text { where: } \\
& \mathrm{II}=\text { intensity of infection; } \\
& \mathrm{n}=\text { number of roots } \mathrm{in} \text { each category; } \\
& \mathrm{v}=\text { category of infection; } \\
& \mathrm{N}=\text { total number of evaluated roots. }
\end{aligned}
$$

Fungi from the inoculated plants were re-isolated from the infected plants to prove the Koch's postulates.

Data were subjected to the analysis of variance (ANOVA). The significance was evaluated at $\mathrm{p}<0.05$ for all tests. Statistical analyses were performed by using the STATISTICA v.7.

DNA extraction, polymerase chain reaction amplification and sequencing

A genomic DNA extraction of all monoconidial Fusarium species was done by obtaining a mycelial mat from the potato dextrose broth in Erlenmeyer flasks inoculated with the 7 day 
old pure cultures and making use of DNeasy Plant Mini Kit (Qiagen, Hilden, Germany) according to the manufacturer's instructions. The molecular identity of the fungus was confirmed by amplifying the partial translation elongation factor- $1 \alpha$ (TEF) gene with the specific primers ef1 (ATGGGTAAGGAGGACAAGAC) and ef2 (GGAAGTACCAGTGATCATGTT) (O'Donnell et al., 1998).

The TEF region was amplified in a $25 \mu \mathrm{l}$ reaction mixture containing 12.5 $\mu \mathrm{l} 2 \mathrm{X}$ PCR Master mix (K071, Fermentas, Lithuania), $9 \mu$ RNase-free water, $1.25 \mu$ leach of both forward and reverse primers $\left(100 \mathrm{pmol} \mathrm{ul}^{-1}\right.$, Metabion International, Germany) and $1 \mu \mathrm{l}$ template DNA. The PCR conditions were as follows: pre-denaturation at $94^{\circ} \mathrm{C}$ for $2 \mathrm{~min} ; 35$ cycles of denaturation at $94^{\circ} \mathrm{C}$ for $1 \mathrm{~min}$, annealing at $53^{\circ} \mathrm{C}$ for $1 \mathrm{~min}$, and extension at $72{ }^{\circ} \mathrm{C}$ for $2 \mathrm{~min}$ and final extension at $72{ }^{\circ} \mathrm{C}$ for $10 \mathrm{~min}$. Amplified products were analyzed by $1 \%$ agarose gel electrophoresis, stained with Midori Green DNA Stain (Nippon Genetics), and visualized under a UV transilluminator. The PCR product was sequenced and deposited in the National Center of Biotechnology Information (NCBI) GenBank database. The sequence was compared with sequences in the GenBank database (http://www.ncbi.nlm.nih.gov/BLAST/) by using the ClustalW program (Thompson et al., 1994) and MEGA5 software (Tamura et al., 2011).

\section{Results and Discussion}

\section{Occurrence}

The presence of Fusarium species was detected in three localities in both years. The percentage increase of Fusarium infection on anise seeds in three localities in 2013 was 200$250 \%$ compared to 2012 (Table 1 ).

\section{Morphological characterization}

All seven Fusarium isolates were examined macroscopically and microscopically. During morphological observation, aerial mycelia of all isolates were white at the initial stage, while the underside of colonies became pale pink, violet, purple and brown in the later stages on PDA (Figs. 1a and 2a).

Based on their morphological characteristics (shape, form, separation, size, microconidia, macroconidia, phialides, chlamidospores, sclerotia), the isolates were identified as: A6-F. tricinctum, A7-F. proliferatum, A8-F. equiseti, A9-F. oxysporum, A10-F. sporotrichoides, A11-F. incarnatum and A12-F. verticillioides (Table 2, Figs. 2 and 3 b, c, d, e).

\section{The pathogenicity test}

The results of the pathogenicity test revealed that all seven isolates of Fusarium species are pathogenic to the anise

Table 1. Percentage of Fusarium infected anise seeds during 2012 and 2013 in three localities in Serbia

\begin{tabular}{ccc}
\hline \multirow{2}{*}{ Locality } & \multicolumn{2}{c}{ \% of Fusarium infected seeds } \\
\cline { 2 - 3 } & 2012 & $\begin{array}{c}2013 \\
\text { (\% increase infection) }\end{array}$ \\
\hline Mošorin & 3.75 & $7.5(200.0)$ \\
Veliki Radinci & 4.75 & $11.75(247.4)$ \\
\hline Ostojićevo & 5.50 & $13.75(250)$ \\
\hline
\end{tabular}

seedlings. They showed symptoms like crown rot and root necrosis or root rot. These symptoms were observed within 30 days after inoculation as necrosis and brown discoloration of the root, lower part of the stem necrosis, and a complete rottenness/decomposition. According to the description scale 0-3, the pathogenicity of each Fusarium isolate was classified into three groups: virulent (II > 30): F. oxysporum, F. tricinctum and F. incarnatum, moderately virulent (II $=20-30): F$. proliferatum and $F$. sporotrichoides, and mildly virulent (II < 20):F. equisetiand, F. verticillioides (Table 3). Inoculated fungi were re-isolated from the diseased plants, but not from negative control plants, thus fulfilling the Koch's postulates.

\section{Molecular identification of Fusarium spp.}

To confirm the morphological identification of the seven studied strains (A6, A7, A8, A9, A10, A11 and A12), molecular analyses were performed. Amplification of the TEF gene of the isolates generated a product of expected size (Fig. 3). The amplified and purified DNA fragments of Fusarium isolates were sequenced in both directions. Sequences of amplified TEF gene showed that fragments obtained from seven isolates were 440-651 bp in length. The sequences obtained from the isolates were deposited in the GeneBank (NCBI Acc.No. KP126607-13) (Table 4) and showed 100\% homology (100\% query coverage) with the $F$. tricinctum, $F$. proliferatum, F. equiseti, F. oxysporum, F. sporotrichoides, F. cf. incarnatum and $F$. verticillioides isolates.

Infected seeds contribute significantly to the disease epidemiology. Identification of seeds health status and the use of Fusarium free seeds are the most important steps in disease control. Anise seed infections can result in reduced germination and yield loses (Bottalico, 1998; Perkowski et al., 2002). Until this investigation was conducted, there was no information available on the health status of commercial anise seed production in Serbia.

This study represents the first attempt to characterize pathogens of genus Fusarium associated with anise seeds in Serbia. The Fusarium isolates selected for this investigation from the three localities in Serbia were identified as: $F$. tricinctum, $F$. proliferatum, $F$. equiseti, $F$. oxysporum, $F$. sporotrichoides, F. incarnatum and F. verticillioides species, based on morphological characteristics and proved by the molecular analysis. Bokhari (2007) also isolated 5 Fusarium species: F.oxysporum, F.moniliforme and F. subglutinans in Saudi Arabia on anise seeds. Ghoneem et al. (2012) reported the presence of $F$. equiseti, F. oxysporum, F.incarnatum, F. solani and F.verticillioides on anise seeds in Egypt based on

Table 3. The intensity of infection (II) based on the pathogenicity test on anise seedlings

\begin{tabular}{cc}
\hline Species & The intensity of infection (II)* \\
\hline F. tricinctum & $34 \pm 0.87 \mathrm{c}$ \\
F. proliferatum & $24.5 \pm 087 \mathrm{~b}$ \\
F. equiseti & $19.6 \pm 0.76 \mathrm{a}$ \\
F. oxysporum & $38.5 \pm 1.4 \mathrm{c}$ \\
F. sporotrichoides & $24.5 \pm 3.5 \mathrm{~b}$ \\
F. incarnatum & $31.8 \pm 0.67 \mathrm{c}$ \\
F. verticillioides & $18.7 \pm 1.76 \mathrm{a}$ \\
\hline${ }^{*}$ Means \pm standard deviation followed by the same letter are not significantly
\end{tabular}

${ }^{*}$ Means \pm standard deviation followed by the same letter are not significantly different $(\mathrm{p}<0,05)$, according to Duncan's range test 
Table 2. Morphological characteristics of Fusarium spp. isolated from anise seeds

\begin{tabular}{|c|c|c|c|c|c|c|c|}
\hline & F. tricinctum & F.proliferatum & F. equiseti & F. oxysporum & F. sporotrichioides & F. incarnatum & F. verticillioides \\
\hline Microconidia & + & + & - & + & + & - & + \\
\hline Form & $\mathrm{Lc}$ & $\mathrm{Lc}, \mathrm{Fh}$ & & Fh & & & $\mathrm{Lc}, \mathrm{Fh}$ \\
\hline Phialides & Mono & Mono, poly & Mono & Mono & Mono-poly & Mono-poly & Mono \\
\hline Shape & $\mathrm{Np}$ & $\mathrm{Ov}$ & & $\mathrm{Ov}-\mathrm{El}$ & $\mathrm{Ol}, \mathrm{Py}, \mathrm{El}$ & & $\mathrm{Ov}$ \\
\hline Separation & 0 & 0 & & $0-1$ & $0-1$ & & $0-1$ \\
\hline Size $(\mu \mathrm{m})$ & $\begin{array}{r}7.0-13.0 \\
\times 4.2-7.7\end{array}$ & $\begin{array}{r}3.0-19.5 \\
\times 2.0-5.0\end{array}$ & & $\begin{array}{r}7.5-9.0 \\
\times 3.0-5.5\end{array}$ & $\begin{array}{r}7.0-20.0 \\
\times 4.5-7.5\end{array}$ & & $\begin{array}{r}5.2-18.0 \\
\times 1.1-5.5\end{array}$ \\
\hline Macroconidia & + & + & + & + & + & + & + \\
\hline Shape & $S p$ & $\mathrm{Cr}$ & & Sp & $\mathrm{El}$ & $\mathrm{Sp}-\mathrm{Sr}$ & $\mathrm{Cr}$ \\
\hline Septate & $3-5$ & $3-5$ & $3-5$ & $3-5$ & $3-5$ & $3-5$ & $3-5$ \\
\hline Size $(\mu \mathrm{m})$ & $\begin{array}{r}22.0-48.0 \\
\times 3.5-4.5\end{array}$ & $\begin{array}{r}16.5-73.0 \\
\times 2.5-5.0\end{array}$ & $\begin{array}{r}40.5-57.5 \\
\times 3.75-5.0\end{array}$ & $\begin{array}{r}49.0-89.5 \\
\times 3.0-10.0\end{array}$ & $\begin{array}{r}22.0-45.0 \\
\times 3.5-5.5\end{array}$ & $\begin{array}{l}19.0-62.5 \\
\times 2.0-4.5\end{array}$ & $\begin{array}{r}16.3-79.0 \\
\times 3.0-5.0\end{array}$ \\
\hline Clamidospore & + & - & + & + & + & + & - \\
\hline Sclerotia & + & - & + & - & - & - & - \\
\hline
\end{tabular}

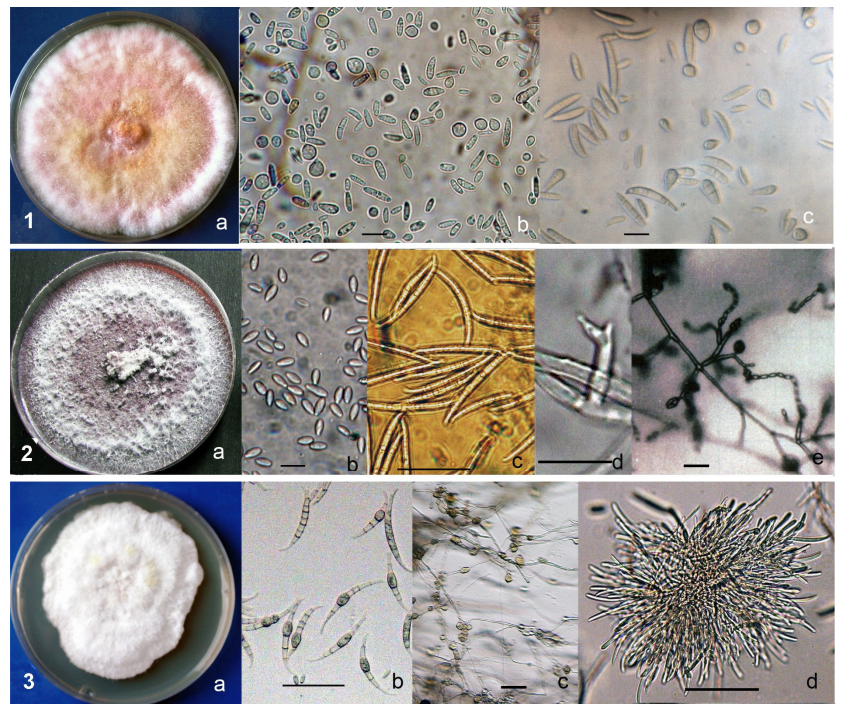

Fig. 1. Morphological characters of Fusarium isolate: $1=F$. tricinctum: a - colony on PDA, b - microconidia, bar - $10 \mu \mathrm{m}, \mathrm{c}-$ micro and macroconidia, bar $-20 \mu \mathrm{m}, 2=$ F.proliferatum: a - colony on PDA, b - microconidia, bar - $20 \mu \mathrm{m}, \mathrm{c}$ - macroconidia, bar - 50 $\mu \mathrm{m}, \mathrm{d})$ polyphialides in sity, bar - $20 \mu \mathrm{m}, \mathrm{e})$ microconidia in chains and false heads on conidiophores in sity, bar $-20 \mu \mathrm{m}, 3=$ F. equiseti: a

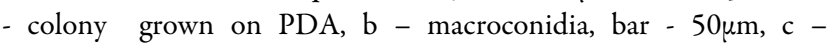
chlamydospores in sity, bar $-40 \mu \mathrm{m}, \mathrm{d}$ ) conidiogenous cells, bar -50 $\mu \mathrm{m}$

morphological and microscopic characteristics. Saleem et al. (2013) used the same method to identify F. merismoides, $F$. oxysporumand $F$. proliferatum on anise seeds in Egypt. Our results confirmed earlier reports that $F$. equiseti, $F$. oxysporum, $F$. incarnatum, $F$. solani, $F$.proliferatumand $F$. verticillioides were present on anise seeds in Serbia. According to our knowledge, this is the first report of $F$. tricinctum and $F$. sporotrichoides presence on anise seeds in the world. As several reports mentioned the impossibility of distinguishing among some Fusarium species, we checked our morphological results with molecular method based on the TEF gene.

The level of anise seed infection with Fusarium species was variable, ranging from 3.75 to $17.75 \%$. The percentage

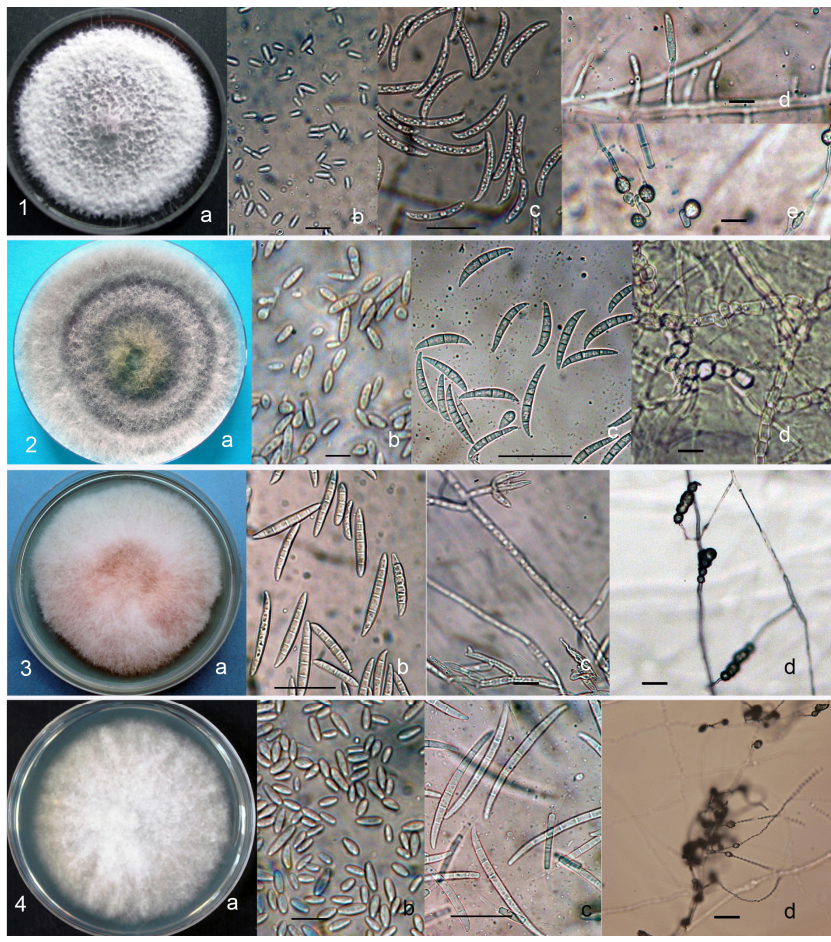

Fig. 2. Morphological characters of Fusarium isolate: $1=F$. oxysporum: a - colony on PDA, b - microconidia, bar - $10 \mu \mathrm{m}, \mathrm{c}$ macroconidia, bar - $50 \mu \mathrm{m}, \mathrm{d}$ ) monophialides, in sity, bar - $20 \mu \mathrm{m}, \mathrm{e})$ chlamydospores, in sity, bar - $10 \mu \mathrm{m}, 2=$ F. sporotrichioides: a - colony on PDA, b - microconidia, bar - $10 \mu \mathrm{m}, \mathrm{c}$ - macroconidia, bar - $50 \mu \mathrm{m}$, d) chlamydospores, in sity, bar $-10 \mu \mathrm{m}, 3=F$. incarnatum: a - colony on PDA, b - macroconidia, bar - $50 \mu \mathrm{m}, \mathrm{c}$ - polyphialides in sity, bar $10 \mu \mathrm{m}, \mathrm{d})$ chlamydospores in sity, bar $-10 \mu \mathrm{m}, 4=F$. verticilioides: a colony on PDA, microconidia, bar - $20 \mu \mathrm{m}, \mathrm{c}$ - macroconidia, bar - 50 $\mu \mathrm{m}, \mathrm{d})$ microconidia in monophyalide chains, in sity, bar - $10 \mu \mathrm{m}$

infection of anise seed with Fusarium species has been increasing from year to year because the infected seeds are used for sowing. In addition, most Fusarium species exists in the soil as chlamydospores which, in favourable conditions, can survive for up to 20 years (Palmero et al., 2014). Chlamydospores present in the soil are the main source of infection. All of the mentioned Fusarium species were transmitted by seeds and 
Table 4. Identification of Fusarium spp. associated with anise seeds based on morphological analysis and TEF gene sequencing

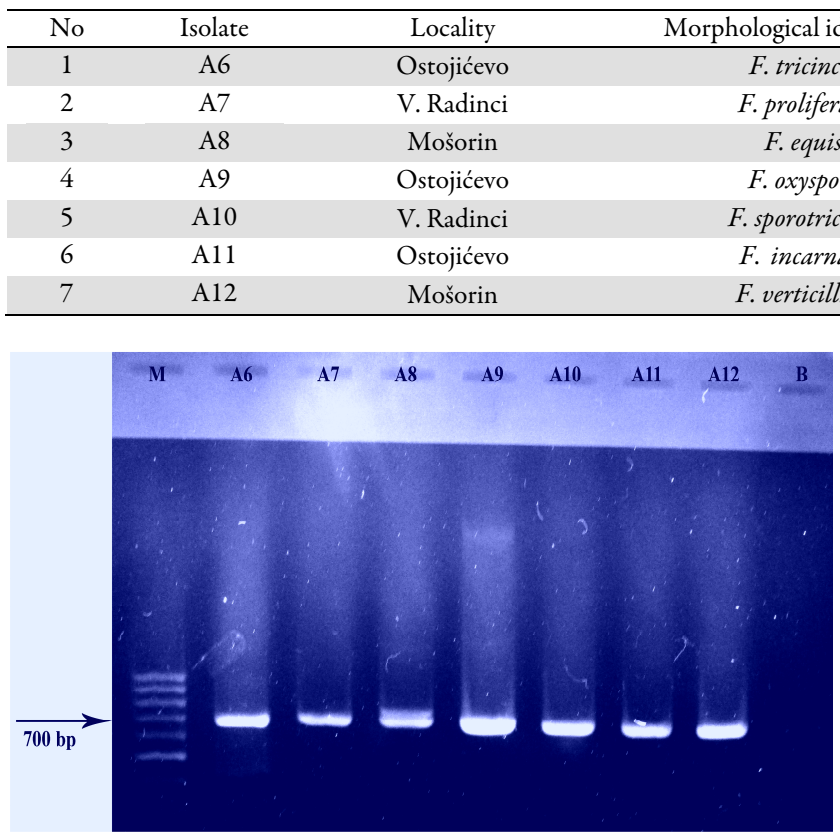

Fig. 3. PCR amplification of the seven Fusarium isolates with primer pair ef1/ef2. Lanes: $M$ - Mass-Ruler ${ }^{\mathrm{TM}} \mathrm{DNA}$ ladder Mix (Fermentas Life Sciences GmgH, Lithuania); 1 - F. tricinctum; 2 - F. proliferatum; 3 - F. equiseti; 4 - F. oxysporum; 5 - F. sporotrichoides; $6-F$. cf. incarnatum; $7-F$. verticillioides; 8 negative template control (PCR mix with RNase-free water)

pathogenic to anise seedlings. On the basis of the pathogenicity test, F. oxysporum, F. tricinctum and F. incarnatum, manifested the highest pathogenicity on the anise plants, followed by $F$. proliferatum, and $F$. sporotrichoides. The lowest pathogenicity was expressed by $F$. equiseti and $F$. verticillioides.

Fusarium species have already been recorded all over the world and are proved to be pathogens of many plants (Boughalleb et al., 2005; Mehl and Epstein, 2007). The virulence may be attributed either to a single gene or to a set of genes that confer a specific characteristic to the pathogen, such as production of host-specific toxins (Friesen et al., 2006; Van der Does and Rep, 2007). F. oxysporum has already been shown as very virulent pathogen. Anise seed has been detected as host to some Fusarium species (Bokhari, 2007; Ghoneem et al., 2012; Saleem et al., 2013), but they didn't prove the pathogenicity. Of the 101 most economically important plants, at least 81 are hosts to Fusarium pathogens (Nayaka $e t$ al., 2013). We added anise as the host plant to the two Fusarium species: F. tricinctum and F. sporotrichoides.

In this study, both morphological and molecular approaches (Leslie and Summerell, 2006) successfully detected the same Fusarium species, because all of our seven Fusarium isolates were precisely identified. Molecular detection based on the TEF gene of Fusarium species on anise seeds could be a powerful tool in identification of the pathogenic species, giving results in a shorter period of time compared to the morphological identification.

Morphological identification, followed by sequencing of TEF region fragments amplified by ef $1 / \mathrm{ef} 2$ primers and BLAST analysis of all our isolates that showed a high level of genetic similarity with DNA sequences of fungal species available in GenBank, confirmed that our isolates were $F$. tricinctum, $F$. proliferatum, $F$. equiseti, $F$. oxysporum, $F$. sporotrichoides, $F$. cf. incarnatum and $F$. verticillioides. In conclusion, this study is the first known extensive research of the characterization of the fungal pathogens associated with anise seed production in Serbia.

The translation elongation factor 1-a (TEF) gene, which encodes an essential part of the protein translation machinery, has high phylogenetic utility because it is highly informative at the species level in Fusarium. Non-orthologous copies of the gene have not been detected in the genus and universal primers have been designed that barcode successfully amplify this region for all species of the genus (Summerell et al., 2003; Geiser et al., 2004; Kristensen et al., 2005).

The results obtained in this study and a successful application of the molecular identification protocol to identify Fusarium species based on the TEF gene sequence (which codes for the factor- $1 \alpha$ ) represent a starting point for the study of phylogeographic distribution of Fusarium sp in Serbia. It is also useful to have a clear genetic characterization and an effective method for species identification. The ability to sequence a large number of isolates by using additional genome parts and being able to compare their relationship with other isolates, all contribute to a precise identification of Fusarium population. This can lead to an effective control of these dangerous pathogens.

Generally, a management of root rot disease, caused by Fusarium species, is usually based on the crop rotations to reduce the inoculum levels in soil (Davis et al., 2006) as well as using healthy seeds or genetically resistant cultivars. In protection of anise seeds of Fusarium species we could use beneficial bacterial strains which demonstrate an antagonistic effect to fungi.

\section{Conclusions}

Based on morphological, microscopic characteristic and molecular identification by sequencing of TEF gene we proved the presence of $F$. tricinctum, $F$. proliferatum, $F$. equiseti, $F$. oxysporum, F. sporotrichoides, F. incarnatum and F. verticillioides species on anise seeds in three localities in Serbia during 2012 and 2013. Based on our knowledge and research, this is the first report of $F$. tricinctum and F. sporotrichoides presence on anise seeds in the world.

\section{Acknowledgements}

This work was supported by the Ministry of Education, Science and Technological Development, Republic of Serbia (grant number TR31018). 
416

\section{References}

Bokhari FM (2007). Spices Mycobiota and Mycotoxins available in Saudi Arabia and their abilities to inhibit growth of some toxigenic fungi. Mycrobiology 35:45-53.

Bottalico A (1998). Fusarium disease of cereals: species complex and related mycotoxin profiles, in Europe.Journal of Plant Pathology 80:85-103.

Boughalleb N, Armengol J, El Mahjoub M (2005). Detection of races 1 and 2 of Fusarium solani f. sp. cucurbitae and their distribution in watermelon fields in Tunisia. Journal of Phytopathology 153:162-168.

Bulajić A, Djekić I, Lakić N, Krstić B (2009). The presence of Alternaria spp. on the seed of Apiaceae plants and their influence on seed emergence. Archives of Biological Sciences 61:871-881.

Davis RM, Colyer PD, Rothrock CS, Kochman JK (2006). Fusarium wilt of cotton: population diversity and implications for management. Plant Disease 90:692-703.

Desjardins AE (2006). Fusarium Mydotoxins: Chemistry, Genetics and Biology. American Phytopathological Society (APS Press), St Paul. Minnesota.

Dražić S, Živanović T, Prodanović S (2007). Stability of productive traits of genotypes of cultivated medicinal plants of the family Apiaceae. Biotechnology \& Biotechnological Equipment 21:100-106.

Duncan KE, Howard RJ (2010). Biology of maize kernel infection by Fusarium verticillioides. Molecular Plant Microbe Interactions 23:6-16.

Essono G, Ayodele M, Akoa A, Foko J, Olembo S, Goskowski J (2007). Aspergillus species on cassava chips in storage in rural areas of southern Cameroon: their relationship with storage duration, moisture content and processing methods. African Journal of Microbiology Research 1:18.

Fandohan P, Hell K, Marasas WFO, Wingfield MJ (2003). Infection of maize Fusarium species and contamination with fumonisin in Africa. African Journal of Biotechnology 12:570-579.

Filion M,St-Arnaud M,Jabaji-HareSH(2003). Quantification of Fusarium solani f. sp. phaseoli in mycorrhizal bean plants and surrounding mycorrhizosphere soil using real-time polymerase chain reaction and direct isolations on selective media. Phytopathology 93:229-235.

Friesen TL, Stukenbrock EH, Liu ZH, Meinhardt S, Ling H, Faris JD, Rasmussen JB, Solomon PS, McDonald BA, Oliver RP (2006). Emergence of a new disease as a result of interspecific virulence gene transfer. NatureGenetics 38:953-956.

Frisvad JC, Thrane U, Samaon RA, Pit, JI (2006). Important mycotoxins and the fungi which produce them. In: Hocking AD, Pitt JI, Samson RA, Thane U (Eds). Advances in Food Mycology. Springer-Verlag US pp3-31.

Geiser DM, Jimenz Gasco MM, Kang S, Mkalowska I, Veeraraghavan N, Ward TJ, Zhang N, Kuldau GA, O’Donnell K (2004). FUSARIUMIDv.1.0: ADNA sequence database for identifying Fusarium. European Journal of Plant Pathology 110:473-479.

Ghoneem KM, Al Sahli AA, Rashad YM (2012). Detecting of Verticillium dablia on anise seeds using a new seed health testing technique. African Journal of Microbiology Research 6:1171-1177.
Jackson L, Jablonski J (2004). Fumonisins. In: Magan N, Osen M (Eds). Mycotoxins in food. Woodhead Publishing Ltd and CRC Press, LLC Abington, Cambridge, England pp 384422.

Kristensen R, Torp M, Kosiak B, Holst-Jensen A (2005). Phylogeny and toxigenic potential is correlated in Fusarium species as revealed by partial translation elongation factor 1 alpha gene sequences. Mycological Research 109(02):173-186.

Leslie JF, Summerell BA (2006). The Fusarium Laboratory Manual. Blackwell Publishing, UKpp 388.

Madania A, Altawil M, Naffaa W, Volker P, Hawat M (2013). Morphological and Molecular Characterization of Fusarium Isolated From Maize in Syria.Journal of Phytopathology 161:452-458.

Mathur SB, Kongsdal O (2003). Common laboratory seed health testing methods for detecting fungi. International Seed Testing Association (1thEd), Switzerland.

Mehl HL, Epstein L (2007). Identification of Fusarium solani f. sp. cucubitac race 1 and race 2 with PCR and production of disease free pumpkin seeds. Plant Disease 91:1288-1292.

Moya-Elizando EM (2013). Fusarium crown rot disease: Biology, interactions, management and function as a possible sensor of global climate change. Cienciae Investigación Agraria 40:235-252.

Nayaka SC, Ramana MV, Udayashankar AC, Niranjana SR Mortensen CN, Prakash HS (2013). Chemical and molecular methods for detection of toxigenic fungi and their mycotoxins from major food crops. In: Gupta V, Tuohy M, Ayyachamy M, Turner KM, O'Donovan A (Eds). Laboratory Protocols in Fungal Biology. Springer, New Yorkpp 73-90.

O’Donnell K, Kistler HC, Cigelink E, Ploetz RC (1998). Multiple evolutionary origins of the fungus causing Panama disease of banana: Concordant evidence from nuclear and mitochondrial gene genealogies. Proceedings of the National Academy of Science USA 95:2044-2049.

Orav A, Raal A, Arak E (2008). Essential oil composition of Pimpinella anisum L. fruits from various European countries. Natural Product Research 22:227-232.

Palmero D Rubio-Moraga A, Glavez-Paton L, Nogueras J, Abato C, Gomez-Gomez L, Ahrazem O (2014). Pathogenicity and genetic diversity of Fusarium oxsysporum isolates from corms of Crocus sativus. Industrial Crops and Products 61:186-192.

Perkowski J, Pavlova A, Štrobarova A, Stanchowiak J, Golinski P (2002). Group B trichothecenes biosynthesis in wheat cultivars after heads inoculation with Fusarium culmorum isolates. Biologia 57:765-771.

Ristić D, Pavlović S, Trkulja N, Aćimović M, Pfaf-Dolovac E, Dolovac N, Starović M (2015). Morphological and molecular identification of Fusarium subglutinans, pathogen of anise seed in Serbia. In: Kovačević D (Ed). Book of proceedings of VI “Agrosym 2015”,15-18 Oct 2015. Jahorina, BIH, pp 919-923.

Saber WIA, Ghoneem KM, El-Metwally MM (2009). Identification of Puccinia pimpinellae on Anise plant in Egypt and its control. Plant Pathology Journal 8:32-41.

Saleem A, El-Said AHM, Moharram AM, Abdelnaser EG (2013). Cellulolytic activity of fungi isolated from anise and cumin spices and potential of their oils as antifungal agents. Journal of Medicinal Plants Research 7:1169-1181. 
Sauerborn J, Dorr I, Abbasher A, Thomas H, Kroschel J (1996). Electron microscopic analysis of the penetration process of Fusarium nygamai, a hyperparasite of Striga hermonthica. Biological Control 7:53-59.

Simon JE, Chadwick AF, Craker LE (1984). In herbs, an indexed bibliography, 1971-1980. Amsterdam: Elsevier.

SkandamisP, Koutsoumanis K, Fasseas K, Nychas GJE (2001).Inhibition of oregano essential oil and EDTA on E. coli O157:H7. European Journal of Plant Pathology 116:211-224.

Summerell BA, Salleh B, LeslieJF (2003). A utilitarian approach to Fusarium identification. Plant Disease 87:117-128.

Tamura K, Peterson D, Peterson N, Stecher G, Nei M, Kumar S (2011). MEGA5: Molecular Evolutionary Genetics Analysis using Maximum Likelihood, Evolutionary Distance, and Maximum Parsimony Methods. Molecular Biology and Evolution 28:2731-2739.

Thompson JD, Higgins DG, Gibson TJ, Clustal W (1994). Improving the sensitivity of progressive multiple sequence alignment through sequence weighting, position-specific gap penalties and weight matrix choice. Nucleic Acids Research 22:4673-4680.
Van der Does HC, Rep M (2007). Virulence genes and the evolution of host specificity in plant-pathogenic fungi. Molecular Plant-Microbe 20:11751182.

Wang H, Xiao M, Kong F, Chen S, Dou HT, Sorrell T, Li RY, Xu YC (2011). Accurate and practical identification of 20 Fusarium species by seven-locus sequence analysis and reverse line blot hybridization, and an in vitro antifungal susceptibility study. Journal of Clinical Microbiology 49:1890-1898.

Zhu Z, Zheng L, Pan L (2014). Identification and characterization of Fusarium species associated with wilt of Eleocharis dulcis (Chinese water chestnut) in China. Plant Disease 98:977-987. 